\title{
Factors Affect to Stolon Formation and Tuberization in Potato: A Review
}

\author{
P.D. Abeytilakarathna
}

10.18805/ag.R-187

\begin{abstract}
Potato tuber formation is a complex process that is induced by a mobile signal called tuberigen. It involves several genes such as AtBMI, St 14-3-3s, StBEL, StBELL11, StBELL29, StBMI1-1, StCDF1, StCEN, StCO, StFDL1, StFT, StGA2ox1, StGA3ox2, StMSI1, StSP6A. This article focuses on important factors such as genetic factors, low temperature, high irradiation, low nitrogen, abscisic acid, chlormequat chloride, auxin, Jasmonic acid, cytokinin and paclobutrazol that induce tuber formation while ethylene, drought, low irradiation, high-temperature that reduce or inhibit tuber initiation.
\end{abstract}

Key words: Potato, Stolon, Tuber formation, Tuberization.

Potato (Solanum tuberosum L.) is one of the major food crops, after rice, wheat and maize which is grown in more than 140 countries worldwide (Horton 1987; Hunsigi and Krishna, 1998). According to Wasilewska-Nascimento et al. (2020), potato production and area under cultivation have increased dramatically by more than $100 \%$ in most of the countries in tropics and subtropics like India, Indonesia, Kenya, Bangladesh, China, Egypt and Peru while it has declined in temperate countries like France, Germany, Ireland, Italy and Poland during last 50 years. But the productivity of the potatoes is greater (more than $45 \mathrm{t} \mathrm{ha}^{-1}$ ) in Germany, the Netherlands and the USA like high input usage countries than the other countries (Koch et al., 2020). Consequently, reviewing the factors that influencing stolons and tuber formation in potatoes, based on the most important experiments conducted under different climatic condition are very important to get an understanding of yield formation of potato as well as enhance its tuber yield even under extreme conditions especially in the tropical and sub-tropical regions.

Jefferies and Lawson (1991) described the seven growth stages of potato plants: seed germination and emergence, tuber dormancy, tuber sprouting, emergence and shoot expansion, flowering, tuber development and senescence.

\section{Formation of stolons and tubers in potatoes}

The formation of underground stolon and tuberization are the two processes of tuber formation of potato (Hunsigi and Krishna, 1998; Jackson, 1999). An early phase of the stolon tip begins to swell is considered as the tuberization. Diageotropically growing underground lateral buds are developed into stolons by elongation and transverse division of its apical cells (Xu et al., 1998). Xylem tissues of stolons that are situated in between inner and outer phloem tissues are called a pre-medullary zone. At the time of tuber formation, the apoplastic phloem unloading pathway of assimilates through the cells is changed into a symplastic pathway through the cytoplasm and start to swelling of stolon
Department of Agriculture, Agricultural Research Station, Seetha Eliya, Nuwara Eliya, Sri Lanka.

Corresponding Author: P.D. Abeytilakarathna, Department of Agriculture, Agricultural Research Station, Seetha Eliya, Nuwara Eliya, Sri Lanka. Email: abeytilaka@yahoo.com

How to cite this article: Abeytilakarathna, P.D. (2021). Factors Affect to Stolon Formation and Tuberization in Potato: A Review. Agricultural Reviews. DOI: 10.18805/ag.R-187.

Submitted: 28-12-2020 Accepted: 28-10-2021 Online: 19-11-2021

tip by longitudinally dividing the pith and cortex cells. Cells in the pre-medullary zone are divided further with the enlargement of potato tubers. Finally, the tuber size is increased by dividing and enlarging the storage parenchyma cells in the outer cortex of tubers (Hunsigi and Krishna, 1998; Xu et al., 1998; Viola et al., 2001; Akoumianakis et al., 2016; Zhang et al., 2020). Active numbers of tubers per haulm decrease by resorption or remain as very small tubers. The first three weeks after emergence is the most critical period for tuber formation. If anything happens to slow down the growth of plants, it affects negatively final yield (Cho and Iritani, 1983; Oliveira and Da, 2000; Walworth and Carling, 2002; Thornton et al., 2007). The numbers of tubers per plant are determined by different parameters such as numbers of stolons and stems, varieties grown and status of vegetative growth (Wurr et al., 1997; Adhikari, 2005). For instance, stolon length is a varietal character (Kratzke and Palta, 1992). According to Celis-Gamboa (2002) stolons were formed 29 days after planting in all maturity types (very early, early, intermediate, late, or very late) of potatoes. Besides, tuberization was begun 29 days after planting in very early maturity types and 36 days after planting in other maturity types.

\section{Genetical regulation of tuber formation}

Tuberization, stolons length, number of tubers per plant, tuber size and uniformity are highly heritable and genetically 
advance in potatoes. Besides, the number of tubers per plant is positively correlated with the final tuber yield, it is least influenced by the prevailing environmental factors such as day length, light intensity and temperature (Tripura et al., 2016; Hulscher et al., 2013; Bahram et al., 2020). Tuber formation of potato is induced by the mobile signal initiated in leaves called tuberigen and it involves FLOWERING LOCUS T (FT) protein (Rodriguez-Falcon et al., 2006; Abelenda et al., 2011). The authors revealed that several genes are responsible for tuber formation in potatoes. A transcription factor StBEL5 mRNA that is produced in leaves mobilizes to the stolon tips through the phloem tissue to initiate tubers under a favourable condition with a short-day photoperiod. Potato varieties having overexpression of StBELL5 produce higher yields due to early tuberization. Full-length mRNA StBELL11 and StBELL29 affect to tuberization of potatoes (Chen et al., 2003; Banerjee et al., 2006; Kloosterman et al., 2013; Lin et al., 2013; Sharma et al., 2016; Hannapel and Banerjee, 2017; Hannapel et al., 2017). The gene StBELL5 induces the activity of SELFPRUNING 6A (StSP6A) which interacts with FLOWERING LOCUS $D(F D)$-like protein in stolons during the tuber initiation. CYCLING DOF FACTOR1 (StCDF1) or overexpression of StSP6A and its interaction with St 14-3$3 s$ induce early tuber initiation while StFDL 1 delays tuber formation. Besides, overexpression of CONSTANS (CO)like gene StCO cause to delay the tuber initiation under noninductive conditions either during short days or long days. StCO also affects the level of StBEL5 mRNA level. FT-like protein, StFT/ StSP6A transcript level is also induced initiation of tuber formation in wild-type potato plants. Tuberization signal of StSP6A is co-expressed with TERMINAL FLOWER1/ CENTRORADIALIS genes (StCEN) and it is suppressed by StFDL1 (Rodriguez-Falcon et al., 2006; Navarro et al., 2011; Gonzalez-Sachain et al., 2012; Sharma et al., 2016; Hannapel et al., 2017; Teo et al., 2017; Zhang et al., 2020). StMSI1 which belongs to the group of POLYCOM REPRESSIVE COMPLEXES (PRC) protein and micro RNA 156 (miR156) increases the stolon formation while PRC protein: StBMI1-1 decreases the number of stolons under short-day photoperiod conditions. Overexpression of PRC protein AtBMI1 stimulates the formation of aerial tubers that causes to reduce the underground tuber yield under short-day conditions. Micro RNA 172 (miR172) also influences tuber formation in potatoes (Martin et al., 2009: Kumar et al., 2020). Lipoxygenases (LOX1) transcription factor restricts the development of root and stolons and it regulates the tuber enlargement by accumulating in the apical part of small tubers. The genes; GA2-oxidase (StGA2ox1) and GA3oxidase (StGA3ox2) are induced in stolons under the shortday condition and overexpression of StGA20x1 and StGA3ox2 genes induce early tuberization by control the gibberellins (GA) level in stolons (Kolomiets et al., 2001; Kloosterman et al., 2007; Bou-Torrant et al., 2011). The cDNA fragments that express during the tuber initiation period are very important as genetic markers for selection phenotypic variation in the potato breeding programs (Strunik et al., 1999).

\section{Effect of growth regulators on tuber formation}

Several growth regulators affect to stolons and tuber formation of potatoes. Among these, gibberellins (GA) is one of the most important growth regulators and it involves stolon elongation and inhibition of tuber formation in potatoes by affecting starch hydrolase activity or starch synthesis enzymes. GA-oxidase genes are involved to change GA content in the stolon tip before the onset of tubers. $\mathrm{GA}_{1}$ and $\mathrm{GA}_{3}$ present in stolon at tuber initiation and active $\mathrm{GA}$ decrease with swelling of stolon tip under inducing condition (Smith and Palmer, 1970; Xu et al., 1998; Abdala et al., 2002; Kloosterman et al., 2007; Roumeliotis et al., 2012). Degebasa (2020) pointed out that the dipping of tubers in $\mathrm{GA}_{3}$ at a rate of $50 \mathrm{ppm}$ for $24 \mathrm{hrs}$ just after harvest, increased the average number of tubers per plant along with the increasing total and marketable tuber yields. But contradictory results were reported by Kumar et al., (1981) using a low concentration of $\mathrm{GA}_{3}$ at a rate of 1,5 and 10 ppm for $24 \mathrm{hrs}$. It reduced dry matter yield with a significantly increasing number of tubers without changing the numbers of stolons per plant. According to Wang et al. (2018), $\mathrm{GA}_{3}$ treatment with calcium nitrate improved the number of tuber per plant as well as tuber weight in aeroponic grown potatoes. A study conducted five decades ago by Dyson (1965) confirmed that there was no yield reduction with $\mathrm{GA}_{3}$ applied to tuber pieces even delays the tuber growth. According to the studies of Struik et al. (1989), foliar application of $\mathrm{GA}_{3}$ at the rate of $25 \mathrm{ppm}$ at an early stage or 60 days after planting reduced dry matter yield but increased fresh yield and number of tubers per plant by applying 40 days after planting. Menzel (1983) pointed out that tuberization was inhibited by gibberellins produced in buds under warm temperatures. Therefore, further researches are needed to confirm the effects of tuber treating with $\mathrm{GA}_{3}$ or foliar application of gibberellin inhibitors on the total and marketable yields under warm temperature.

The stable concentration of abscisic acid (ABA) is found in the apex portion of the tuber under inducing and noninducing conditions while GA distributes throughout the tuber tissues. Even though ABA can decrease the formation of tubers and stolons, its exogenous application induces tuber formation by counteracting with gibberellins. (Krauss et al., 1981; Xu et al., 1998).

The most popular GA biosynthesis inhibitor used for commercial potato cultivation is chlormequat chloride (CCC). Foliar application of CCC improves the number of tubers formed and yield of small tubers in both fields grown and hydroponic grown potatoes. Soil application of CCC at emergence is also possible as it induces early tuberization by decreasing stolon growth (Dayson, 1965; Rex, 1992; Wijaya et al., 2017). Dahyabhai (2004) observed a significantly higher total tuber yield $(79.9 \%)$ and a greater number of tubers per plant $(32 \%)$ than control by a single application of CCC at the rate of 800 ppm at 45 days after 
planting. But further studies need to confirm the effect of CCC on the yield performance of potatoes due to it may interact with the fertilizer rates, especially the rate of nitrogen and with the different maturity groups.

Some authors did experiments using paclobutrazol which is another GA biosynthesis inhibitor and growth retardant. It also enhanced the number of tubers per plant when applying before tuberization but its high concentration (250 $\mathrm{mg} \mathrm{L}^{-1}$ ) reduced the yield (Lopez et al., 2011; Ellis et al., 2020). Uniconazole and Prohexadione-calcium can also inhibit the GA biosynthesis but their foliar application does not affect the number of tubers formed or the final yield. (Lopez et al., 2011; Ellis et al., 2020).

Kinetin which is one of the adenine-type of cytokinins can inhibit tuberization when adding to the culture medium, but it induces tuber formation with a $6 \%$ or higher concentration of sucrose in in-vitro media. Thidiazuron which belongs to the phenyluron-type of cytokinin and kinetin induce early tuberization, rapid stolon growth and enhance the number of tubers by stimulating basal acid invertase activity (Palmer and Smith, 1970; Pelacho and Mingo-Castel, 1991; Kefi et al., 2000; Aksenova et al., 2009). Another adenine type of cytokinins: 6- benzyl amino purine (BAP) and zeatin riboside promote tuber formation by increasing glycolysis and ATP synthesis activity (Mauk and Langille, 1978; Cheng et al., 2019).

Auxin plays a vital role in tuber formation by inducing tuberization at higher concentrations in stolon before swelling of tubers. Low concentration (2 ppm) of Indole acetic acid (IAA) improves tuberization while its higher concentration (4 ppm) inhibits both stolon elongation and tuberization (Roumeliotis et al., 2012a; Roumeliotis et al., 2012 b; Wang et al., 2018; Xu et al., 1998).

Jasmonic acid $(\mathrm{JA})$ is also one of the important growth regulators in point of tuberization. It accumulates in the root during the tuber formation stage by improving tuber formation and the number of tubers per plant. The exogenous application of $\mathrm{JA}$ on the stolon tip causes to initiate the tuberization. Authors revealed that JA synthesis is stimulated by theobromine which is extracted from Lasiodiplodia theobromae fungus (Pelacho and MingoCastel, 1991; Abdala et al., 2002; Cenzano et al., 2003; Gao et al., 2003). Jackson and Willmitzer (1994) revealed that the tuber did not form by spraying JA up to $100 \mu \mathrm{M}$ on Solanum andigena (Jus. and Buk.) and S. demissum (Lindl.) potatoes under non inducing condition.

Ethylene is also crucial in tuber formation. It inhibits tuber formation, stolon and root elongation by counteracting with kinetin. Foliar application of ethephone promotes tuber formation but it reduced the weight of marketable tubers (Mingo-Castel et al., 1974; Vreugdnhil and Dijk, 1989; Rex, 1992).

\section{Effect of nitrogen on tuber formation}

There is no doubt of the importance of soil nitrogen management for achieving a greater yield. Nitrogen absorbs by plants through the root system as nitrate-nitrogen $\left(\mathrm{NO}_{3}\right.$ $\mathrm{N})$ or ammonium-nitrogen $\left(\mathrm{NH}_{4}-\mathrm{N}\right)$. Lower optimum level (22 $\mathrm{mg} \mathrm{kg}{ }^{-1}$ ) of soil $\mathrm{NO}_{3}-\mathrm{N}$ is required for obtaining maximum yield (Nurmanov et al., 2019). $\mathrm{NO}_{3}-\mathrm{N}$ increases the number of stolons and tubers per plant when applied during the tuber initiation stage. $\mathrm{NH}_{4}-\mathrm{N}$ promotes early tuberization but a low number of stolons and tubers per plant (Gao et al., 2014; Qiqige et al., 2017). According to Dingenen et al. (2019), under a limited supply of nitrogen; the number of tubers per plant was reduced in potato varieties Andigena, Desiree, Saturna, Milva and Alegria by $71.4 \%, 66.7 \%, 75 \%, 75 \%$ and $40 \%$ respectively. Olivera and $\mathrm{Da}(2000)$ revealed that the tuber number per plant was increased by $55.3 \%$ with increasing nitrogen from $40 \mathrm{~kg} \mathrm{ha}^{-1}$ to $200 \mathrm{~kg} \mathrm{ha}^{-1}$. Tuber formation is delayed when applying a total amount of nitrogen for basal dressing (Kleinkopf et al., 1981; Olivera and $\mathrm{Da}, 2000$ ) and tuber formation is inhibited by the higher amount of available nitrogen or continuous supply of nitrogen through roots (Sattlemacher and Marschner, 1979; Krauss and Marschner, 1982; Sarkar and Naik, 1998). On the other hand, De la Morena et al. (1994) confirmed that there was no direct effect on the final tuber yield or the number of tubers per plant by split application of nitrogen at different rates. This may be due to the leaching of applied nitrogen as mentioned by Errebhi et al. (1998). They examined that leaching of $\mathrm{NO}_{3}-\mathrm{N}$ was increased with increasing nitrogen rates in basal fertilizers. Consequently, it is important to do further researches to find out clearly whether or not tuberization affect by high-dose soil-applied nitrogen of fieldgrown potatoes.

\section{Effect of temperature on tuber formation}

The optimum temperature for tuber initiation in potatoes is in the range of 15 to $25^{\circ} \mathrm{C}$ temperature. High temperature $30 / 25^{\circ} \mathrm{C}$ (day/night temperature) or high temperature with low irradiation (3.4 $\mathrm{MJ} \mathrm{m}^{-2} \mathrm{~d}^{-1}$ ) reduce stolons and tuber formation by decreasing photosynthetic efficiency and increasing production of GA in the buds. By increasing temperature in stolons and roots is caused to promote early senesce of plants (Menzel, 1983; Menzel, 1985; Struik et al., 1989; Prange et al., 1990; Lafta and Lorenzen, 1995). Li and Zhang (2020) proved that potato yield was decreased by 583 $\mathrm{kg} \mathrm{ha-1}$ for every increment of temperature by $1^{\circ} \mathrm{C}$ in china. According to Dam et al. (1996), tuber formation is delayed under higher temperatures on long days. Wheeler et al. (1986) observed that tuberization did not occur at $28^{\circ} \mathrm{C}$ either photoperiods of $24 \mathrm{hrs}$ or $12 \mathrm{hrs}$ or $24^{\circ} \mathrm{C}$ at $24 \mathrm{hrs}$ photoperiod of $400 \mu \mathrm{mol} \mathrm{m} \mathrm{m}^{-2} \mathrm{~S}^{-1} \mathrm{PPF}$. The high-temperature effect of potatoes can be mitigated by incorporating organic matter into the soil and mulching with straw-like materials (Paul et al., 2017). Zhang et al. (2020) found that late-maturing cultivars are highly affected by heat than early cultivars.

\section{Effect of photoperiod and light intensity for tuber formation}

It is a well-known fact that the light intensity and duration decide the final yield by controlling photosynthesis and dry 
matter partitioning to the tubers. Likewise, light intensity and duration affect to tuberization of potatoes. For instance, tuber formation is delayed and reduced when exposed to long photoperiods or shading while tuber initiates early when exposed to far-red light. Tuberization also can take place without a dark period if the temperature is low (Wheeler et al., 1986; Demagante and Zaag, 1988; Marwaha and Sandhu, 2002; Plantenga et al., 2016). Cristina et al. (2014) found that the number of daylight hours affects the number of stolons formed in early and intermediated maturing varieties. Presently, most of the commercially cultivated potato varieties do not affect tuberization by the length of the photoperiod (Mackerron and Haverkort, 2004; Kloosterman et al., 2013). After considering these facts, it is crucial to study CCC-like growth regulators to promote tuberization under low irradiation levels with warm environmental conditions. In warmer areas, it may be suitable for growing potatoes during a cloud-free season with abundant sunlight or provide extra light to promote early tuberization and to initiate more tubers. In the cooler area, additional light may be required to enhance yield, especially during the bulking phase. It is important to consider light intensity when conducting experiments on potatoes to draw valid conclusions.

\section{Effect of drought and irrigation on tuber formation}

One of the major limiting factors for the production of potatoes is the limited availability of irrigation water in the tropics and subtropics. Even though water is absorbed by the root system, it can also absorb through the roots of stolons and tubers (Kratzke and Palta, 1985). During water stress, photosynthesis inhibits or reduces due to the closing of stomata (Schapendonk et al., 1989). According to Aliche et al. (2020), stolon and tuber formation are inhibited or reduced under drought conditions by reducing carbon partitioning. Wang et al. (2013) observed that mulch with trickle irrigation is secured more tubers under water deficit conditions. Li and Zhang (2020) revealed that potato yield was increased with every $100 \mathrm{~mm}$ increasing of precipitation in the rainfed area of China. According to Jama-Rodzenska et al. (2020), stolons' weights were higher in cv. Denar and Julinka are under low or optimum water levels than higher water. Tuber yield is reduced by early and midseason moisture stress (Lynch et al., 1995).

\section{CONCLUSION}

Tuber formation in potatoes is a complex process that consists of two processes: stolon formation and tuberization. It is induced by a mobile signal called tuberigen under an inducive condition by involving several genes. Low temperature, high irradiation and some growth hormones: ABA, CCC, kinetin, BAP, Jasmonic acid, low concentration of IAA and paclobutrazol promote tuber formation while Ethelene, high concentration of IAA, drought, low irradiation, high temperature reduce or inhibit tuber formation. Further studies need to clarify the effects of tuber formation by higher soil nitrogen, CCC with different rates of fertilizers and mitigation of high temperature for field-grown potatoes.

\section{REFERENCES}

Abdala, G., Castro, G., Miersch, O. and Pearce, D. (2002). Changes in jasmonate and gibberellins levels during development of potato plants (Solanum tuberosum L.). Plant Growth Regulation. 36: 121-126.

Abelenda, J.A., Navarro, C. and Salome, P. (2011). From the model to the crop: Genes controlling tuber formation in potato. Current Opinion in Biotechnology. 22(2): 287-292.

Adhikari, R.C. (2005). Performance of different size true potato seed seedling tubers at khumaltar. Nepal Agriculture Research Journal. 6: 28-34.

Akoumianakis, K.A., Alexopoulos, A.A., Karapanos, I.C., Kalatzopoulos, K., Aivalakis, G. and Passam, H.C. (2016). Carbohydrate metabolism and tissue differentiation during potato tuber initiation, growth and dormancy induction. Australian Journal of Crop Science. 10(2): 185-192.

Aksenova, N.P., Konstantinova, T.N., Lozhnikova, V.N., Golyanovkaya, S.A. and Sergeeva, L.I. (2009). Interaction between day length and phytohormones in the control of potato tuberization on the in vitro culture. Russian Journal of Plant Physiology. 56(4): 454-461.

Aliche, E.B., Theeuwen, T.P.J.M., Oortwijn, M., Visser, R.G.F. and Linden, C.G.V.D. (2020). Carbon partitioning mechanisms in potato under drought stress. Plant Physiology and Biochemistry. 146: 211-219.

Bahram, D., Saleh, A., Bahman, P. and Reza, M. (2020). Combining ability analysis of tuber yield and related traits in potato. Genetika. 20(1): 215-228.

Banerjee, A.K., Chatterjee, M., Yu, Y., Suh, S.G., Miller, W.A. and Hannapel, D.J. (2006). Dynamics of a mobile RNA of potato involved in a long-distance signalling pathway. Plant Cell. 18: 3443-3457.

Bou-Torrent, J., Martinez-Garcia, J.F., Garcia-Martinez and Prat, S. (2011). Gibberellin A1 metabolism contributes to the control of photoperiod-mediated tuberization in potato. PLoS ONE. 6(9): e24458.

Celis-Gamboa, B.C. (2002). The life cycle of (Solanum tuberosum L.): From crop physiology to genetics. Ph.D. thesis. Laboratory of plant breeding, Wageningen University, Wageningen, The Netherlands.

Cenzano, A., Vigliocco, A., Kraus, T. and Abdala, G. (2003). Exogenously applied jasmonic acid induces changes in apical meristem morphology of potato stolons. Annals of Botany. 91: 915-919.

Chen, H., Rosin, F.M., Prat, S. and Hannapel, D.J. (2003). Interacting transcription factors from the tree-amino acid loop extension superclass regulate tuber formation. Plant Physiology. 132(3): 1391-1404.

Cheng, L., Wang, D., Wang, Y., Xue, H. and Zhang, F. (2019). An integrative overview of physiological and proteomic changes of cytokinin-induced potato (Solanum tuberosum L.) tuber development in vitro. Physiologia Plantarum. 168(3): 675-693.

Cho, J.L. and Iritani, W.M. (1983). Comparison of growth and yield parameters of Russet Burbank for a two year period. American Potato Journal. 60: 569-575. 
Cristina, M., Morar, G., Duda, M. and Todoran, C. (2014). Potato tuberization in long photoperiodic conditions. Agricultura. 91-92(3-4): 24-31.

Dahyabhai, N.D. (2004). Effect of cycocel on growth, yield and quality of potato (Solanum tuberosum L.) cv. Kufri Badshan in middle Gujarat agro-climatic conditions. M.Sc. Thesis. Department Horticulture, B.A. College of Agriculture, Gujarat Agricultural University, Anand Campus, Anand, India.

Dam, J.V., Kooman, P.L. and Struik, P.C. (1996). Effect of temperature and photoperiod on early growth and final number of tubers in potato (Solanum tuberosum L.). Potato Research. 39: 51-62.

De la Morena, I., Guillçn, A. and del Moral, L.F.G. (1994). Yield development in potatoes as influenced by cultivar and the timing and level of nitrogen fertilization. American Potato Journal. 71: 165-173.

Degebasa, A.C. (2020). Treatment of gibberellic acid for vegetative growth, tuber yield and quality of potato (Solanum tuberosum L.) in the central highlands of Ethiopia. Global Journal of Agriculture Innovation, Research and Development. 7: 1-11.

Demagante, A.L. and Zaag, P.V. (1988). The response of potato (Solanum spp.) to photoperiod and light intensity under high temperature. Potato Research. 31: 73-83.

Dingenen, J.V., Hanzalova, K., Salem, M.A.A., Abel, C., Seibert, T., Giaralisco, P. and Wahl, V. (2019). Limited nitrogen availability has cultivar-dependant effect on potato tuber yield and tuber quality traits. Food Chemistry. 288: 170-177.

Dyson, P.W. (1965). Effect of gibberellic acid and (2-chloroethyl)trimethylammonium chloride on potato growth and development. Journal of the Science of Food and Agriculture. 16(9): 542-549.

Ellis, G. D., Knowles, L.O. and Knowwwles, N.R. (2020). Increase the production efficiency of potato with plant growth retardants. American Journal of Potato Research. 97: 88-101.

Errebhi, M., Rosen, C.J., Gupta, S.C. and Birong, D.E. (1998). Potato yield response and nitrate leaching as influenced by nitrogen management. Agronomy Journal. 90(1): 10-15.

Gao, X., Yang, Q., Minami, C., Matsura, H., Kimura, A. and Yoshihara, T. (2003). Inhibitory effect of salicyl hydroxamic acid on theobromine-induced potato tuber formation. Plant Science. 165(5): 993-799.

Gao, Y., Jia, L., Hu. B., Alva, A. and Fan, M. (2014). Potato stolon and tuber growth influenced by nitrogen form. Plant Production Science. 17(2): 138-143.

Gonzalez-Sachain, N.D., Diaz-Mendoza, M., Zurczac, M. and Suarez-Lopez, P. (2012). Potato CONSTANS is involved in photoperiodic tuberization in a graft-transmissible manner. The Plant Journal. 70(4): 678-690.

Hannapel, D.J., Sharma, P. and Banerjee, A.K. (2017). The multiple signals that control tuber formation. Plant Physiology. 174: 845-856.

Hannapel, D.J. and Banerjee, A.K. (2017). Multiple mobile mRNA signals regulate tuber development in potatoes. Plants (Basel). 6: E8.

Horton, D. (1987). Potatoes: Production, marketing and programs for developing countries. Westview Press, Inc., Frederick A. Praeger, Publisher, Colorado, USA. pp 1-3.
Hulscher, M.T., Delleman, J., Eising, J. and Bueren, E.T.L.V. (2013). The inheritance of traits, Potato breeding. Aardappelwereld BV, The Hague, Netherlands, pp 40-63.

Hunsigi, G. and Krishna, K.R. (1998). Science of Field Crop Production. Oxford and IBH Publishing Co Pvt. Ltd., New Delhi, India. pp 353-370.

Jackson, S.D. (1999). Multiple signaling pathways control tuber induction in potato. Plant Physiology. 119(1): 1-8.

Jackson, S.D. and Willmitzer, L. (1994). Jasmonic acid spraying does not induce tuberization in short-day requiring potato species kept in non-inducing conditions. Planta. 194: 155159.

Jama-Rodzenska, A., Walczak, A., Adamczewska-Sowinska, K., Janik, G., Klosowicz, I., Glab, L., Sowinski, J., Chen, X. and Peczkowski, G. (2020). Influence of variation in volumetric moisture content of the substrate on irrigation efficiency in early potato varieites. PloS ONE. 15(4): e0231831.

Jefferies, R.A. and Lawson, H.M. (1991). A key for the stages of development of potato (Solatium tuberosum). Annals of Applied Biology. 119(2) : 387-399.

Kefi, S., Pavlista, A.D., Meagher, M.M. and Read, P.E. (2000). Invertase activity as affected by cytokinin-like compound during potato tuberization in vitro. American Journal of Potato Research. 77: 57-61.

Kleinkopf, G.E., Westermann, D.T. and Dwelle, R.B. (1981). Dry matter production and nitrogen utilization by six potato cultivar. Agronomy Journal 73: 799-802.

Kloosterman, B., Abelenda, J.A., del Mar Gomez, M.C., Oortwijn, M., de Boer, J.M., Kowitwanich, K., Horvath, B.M., van Eck, H.J., Smaczniak, C., Prat, S., Visser, R.G.F. and Bachem, C.W.B. (2013). Naturally occurring allele diversity allows potato cultivation in northern latitude. Nature. 495: 246-250.

Kloosterman, B., Navarro, C., Bijsterbosh, G., Lange, T., Prat, S., Visser, R. G. F. and Bachem, C. W. B. (2007). StGA2ox1 is induced prior to stolon swelling and control GA levels during potato tuber development. The Plant Journal. 52: 362-373.

Koch, M., Naurmann, M. and Pawelzik, E. (2020). The importance of nutrient management for potato production part I: Plant nutrition and yield. Potato Research. 63: 97-119.

Kolomitets, M.V., Hannapel, D.J., Chen, H., Tymeson, M. and Gladon, R.J. (2001). Lipoxygenase is involved in the control of potato tuber development. The Plant Cell. 13(3): 613-626.

Kratzke, M.G. and Palta, J.P. (1985). Evidence for the existence of functional roots on potato tubers and stolons: Significance in water transport to the tuber. American Potato Journal. 62: 227-236.

Kratzke, M.G. and Palta, J.P. (1992). Variations in stolons in length and in incidence of tuber roots among eight potato cultivars. American Potato Journal. 69: 561-570.

Krauss, A. and Marschner, H. (1982). Influence of nitrogen nutrition, day length and temperature on contents of gibberellic and abscisic acid on tuberization in potato plants. Potato Research. 25: 13-21.

Krauss. A. (1981). Abscisic and gibberellic acid in growing potato tubers. Potato Research. 24: 435-439. 
Kumar, A., Kondhare, K. R., Vetal, P. V. and Banerjee, A. K. (2020). PCG proteins MS1 and BMI1 function upstream of miR156 to regulate aerial tuber formation in potato. Plant Physiology. 182(1): 185-203.

Kumar, P., Alka, Rao, P. and Baijial, B.D. (1981). Effect of some growth regulators on plant growth, tuber initiation, yield and chemical composition of potato (Solanum tuberosum L.) Pakistan Journal of Botany. 13(1): 69-75.

Lafta, A.M. and Lorenzen, J.H. (1995). Effect of high temperature on plant growth and carbohydrate metabolism in potato. Plant Physiology. 102(2): 637-643.

$\mathrm{Li}, \mathrm{Q}$. and Zhang, S. (2020). Impacts of recent climate change on potato yield at a provincial scale in Northwest China. Agronomy. 10(3): 426.

Lin, T., Sharma, P., Gonzalez, D. H., Viola, I. L. and Hannapel, D. J. (2013). The impact of the long-distance transport of BEL1-like mRNA on development. Plant Physiology 161: 760-772.

Lopez, R.F., del Castillo, S.F., Pérez,, R.J.E., Aguilar, M.R., León, C.M.T. and Saldaña, L.H. (2011). Paclobutrazol, uniconazole and cycocel in potato seed-tuber production in hydroponic culture. Serie Horticultura. 17(2): 173-182.

Lynch, D.R., Foround, N., Kozub, G.C. and Fames, B.C. (1995). The effect of moisture stress at three growth stages on the yield, components of yield and processing quality of eight potato varieties. American Potato Journal. 72: 375385.

Mackerron, D.K.L. and Harverkort, A.J. (2004). Decision support systems in potato production. Bringing Models to Practice. Wageningen Academic Publishers, Wageningen, The Netherlands. pp 218.

Martin, A., Adam, H., Díaz-Mendoza, M., Zurczak, M., GonzálezSchain, N.D. and Suárez-López, P. (2009). Graft-transmissible induction of potato tuberization by micro RNA miR172. Development. 136: 2873-2881.

Mauk, C.S. and Langille, A.R. (1978). Physiology of tuberization in Solanum tuberosum L.: cis-zeatin riboside in the potato plant: its identification and changes in endogenous levels as influenced by temperature and photoperiod. Plant Physiology. 62: 438-442.

Mawaha, R.S. and Sandhu, S.K. (2002). Yield, growth components and processing quality of potatoes as influenced by crop maturity under short and long days. Advances in Horticultural Science. 2: 79-87.

Menzel, C.M. (1983). Tuberization in potato at high temperatures: gibberellins content and transport from buds. Annals of Botany. 52(5): 697-702.

Menzel, C.M. (1985). Tuberization in potato at high temperatures: Interaction between temperature and irradiance. Annals of Botany. 55: 35-39.

Mingo-Castel, A.M., Negm, F.B. and Smith, O.E. (1974). Effect of carbon dioxide and ethylene on tuberization of isolated potato stolons cultured in vitro. Plant Physiology. 53: 798801.

Navarro, C., Abelenda, J. A., Cruz-Oró, E., Cuçllar, C. A., Tamaki, S., Silva, J., Shimamoto, K. and Prat, S. (2011). Control of flowering and storage organ formation in potato by FLOWERING LOCUS T. Nature. 478: 119-122.
Nurmanov, Y.T., Chernenok, Y.G. and Kuzdanova, R.S. (2019). Potato in response to nitrogen nutrition regime and nitrogen fertilization. Field Crop Research. 231: 115-121.

Olivera, C.A. and Da, S. (2000). Potato crop growth as affected by nitrogen and plant density. Pesquisa Agropecuária Brasileira. 35(5): 939-950.

Palmer, C.E. and Smith, O.E. (1970). Effect of kinetin on tuber formation on isolated stolons of Solanum tuberosum L. cultured in vitro. Plant and Cell Physiology. 11(2): 303314.

Paul, S., Farooq, M., Bhattacharya, S.S. and Gogoi, N. (2017). Management strategies for sustainable yield of potato crop under high temperature. Archives of Agronomy and Soil Science. 63(2): 276-287.

Pelacho, A.M. and Mingo-Castel, A.M. (1991). Jasmonic acid induces tuberization of potato stolons cultured in vitro. Plant Physiology. 97: 1253-1255.

Plantenga, F.D.M., Siakou, M., Bergonzi, S., Heuvelink, E., Bachem, C.W.B., Visser, R.G.F. and Marcelis, L.F.M. (2016). Regulating flower and tuber formation in potato with light spectrum and day length. Acta Horticulturae. 1134: 267-276.

Prange, R.K., McRae, K.B., Midmore, D.J. and Deng, R. (1990). Reduction in potato growth at high temperature: Role of photosynthesis and dark respiration. American Potato Journal. 67: 357-370.

Qiqige, S., Jia, L., Qin, Y., Chen, Y. and Mingshou, F. (2017). Effect of different nitrogen forms on potato growth and development. Journal of Plant Nutrition. 40(11): 1651-1659.

Rex, B.L. (1992). Effect of two plant growth regulators on the yield and quality of Russet Burbank potatoes. Potato Research. 35: 227-233.

Rodriguez-Falcon, M., Bou, J. and Prat, S. (2006). Seasonal control of tuberization in potato: conserved elements with the flowering response. Annual Review of Plant Biology. 57(1): 151-180.

Roumeliotis, E., Kloosterman, B., Oortwijn, Kohlen, W., Bouwmeester, H.J., Visser, R.G.F. and Bachem, C.W.B. (2012 a). The effect of auxin and strigolactones on tuber initiation and stolon architecture in potato. Journal of Experiment Botany. 63(12): 4539-4548.

Roumeliotis, E., Visser, R.G.F. and Bachem, C.W.B. (2012b). A crosstalk of auxin and GA during tuber development. Plant Signal and Behavior. 7(10): 1360-1363.

Sarkar, D. and Nalik, P. (1998). Effect of inorganic nitrogen nutrition on cytokinin-induced potato microtuber production in vitro. Potato Research. 41: 211-217.

Sattelmacher, B. and Marschner, H. (1979). Tuberization in potato plants as affected by application of nitrogen to the roots and leaves. Potato Research. 22: 49-57.

Schapendonk, A.H.C.M., Spitters, C.J.T. and Groot, P.J. (1989). Effect of water stress on photosynthesis and chlorophyll fluorescence of five potato cultivars. Potato Research. 32: 17-32.

Sharma, P., Lin, T. and Hannapel, D. J. (2016). Target of StBELL5 transcription factor include the $F T$ ortholog StSP6A. Plant Physiology. 170: 310-324.

Smith, O.E. and Palmer, C.E. (1970). Cytokinin-induced tuber formation on stolons of Solanum tuberosum. Physiologia Plantarum. 23(3): 599-606. 
Factors Affect to Stolon Formation and Tuberization in Potato: A Review

Struik, P.C., Geertsema, J. and Custers, C.H.M. (1989). Effect of shoot, root and stolon temperature on the development of the potato (Solanum tuberosum L.) plant. I. Development of the haulm. Potato Research. 32: 133-141.

Struik, P.C., Kramer, G. and Smit, N.P. (1989). Effect of soil applications of gibberellic acid on the yield and quality of tubers of Solanum tuberosum L. cv. Brintje. Potato Research. 32: 203-209.

Strunik, P.C., Vreugdenhil, D., VanEck, H.J., Bachem, C.W. and Visser, R.G.F. (1999). Physiological and genetic control of tuber formation. Potato Research. 42: 313-331.

Teo, C.J., Takahashi, K., Shimizu, K., Shimamoto, K. and Taoka, K. (2017). Potato tuber induction is regulated by interactions between components of a tuberigen complex. Plant Cell Physiology. 58(2): 365-374.

Thornton, M., Pavek, M. and Bohl, W.H. (2007). Importance of tuber set and bulking rate. Proceedings of the Idaho Potato Conference, January 17, 2007. University of Idaho, Pocatello, Idaho, USA.

Tripura, A., Das, A., Das, B., Priya, B. and Sarkar, K.K. (2016). Genetic studies of variability, character association and path analysis of yield and its component traits in potato (Solanum tuberosum L.). Journal of Crop Science and Weed. 12(1): 56-63.

Viola, R., Roberts, A.G., Haupt, S., Gazzani, S., Hancock, R.D., Marmiroli, N., Machray, G.C. and Oparka, K.J. (2001). Tuberization in potato involves a switch from apoplastic to symplastic phloem unloading. The Plant Cell. 12: 385-398.

Vreugdenhil, D. and Dijk, W.V. (1989). Effect of ethylene on the tuberization of potato (Solanum tuberosum) cutting. Plant Growth Regulation. 8: 31-39.

Walworth, J.L. and Carling, D.E. (2002). Tuber initiation and development in irrigated and non-irrigated potatoes. American Journal of Potato Research. 79: 387-395.

Wang, C.C., Wang, X.Y., Wang, K.X., Hu, J.J., Tang, M.X., He, W. and Zaag, P.V. (2018). Manipulating aeroponically grown potatoes with gibberellins and calcium nitrate. American Journal of Potato Research. 95: 351-361.

Wang, D., Cheng, L., Wang, Y. and Zhang, F. (2018). Comparative proteomic analysis of potato (Solanum tuberosum L.) tuberization in vitro regulated by IAA. American Journal of Potato Research. 95: 395-412.
Wang, Y.M., Chai, Q. and Zhang, H.J. (2013). Effect of water deficit at tuber initiation on potato (Solanum tuberosum) tuber yield and efficiency of water use. In: H. Li, Q. Xu and H. Ge (Eds.). Advance Material Research. 864-867: 20612064.

Wasilewska-Nascimento, B., Boguszewska-Mañkowska, D. and Zarzyñska, K. (2020). Challenges in the production of high-quality seed potatoes (Solanum tuberosum L.) in the tropics and subtropics. Agronomy. 10: 260-275.

Wheeler, R.M., Steffen, K.L., Tibbitts, T.W. and Palta, J.P. (1986). Utilization of potatoes for life support system II. The effects of temperature under $24-\mathrm{H}$ and $12-\mathrm{H}$ photoperiods. American Potato Journal. 63: 639-647.

Wijaya, H., Slameto and Hariyona, H. (2017). Effect of cycocel concentration on result of mini potato tubers (Solanum tuberosum L.) in hydroponic substrate. International Journal of Science, Engineering and Information Technology. 2(1): 41-44.

Wurr, D.C.E., Hole. C.C., Fellows, J.R., Milling, J., Lynn, J.R. and O'Brien, P.J. (1997). The effect of some environmental factors on potato tuber numbers. Potato Research. 40(3): 297306.

Xu, X., van Lammeren, Vermeer, E. and Vreugdenhil, D. (1998). The role of gibberellins, abscisic acid and sucrose in the regulation of potato tuber formation in vitro. Plant Physiology. 177: 575-584.

Xu, X., Vreugdenhil, D. and van Lammeren, A.A.M. (1998). Cell division and cell enlargement during potato tuber formation. Journal of Experimental Botany. 49(320): 573-582.

Zhang, G., Tang, R., Niu, S., Si, H., Yang, Q., Bizimungu, B., Regan, S. and Li, X.Q. (2020). Effect of earliness on heat stress tolerance in fifty potato cultivars. American Journal of Potato Research. 97: 23-32.

Zhang, X., Campbell, R., Ducreux, L.J.M., Morris, J., Hedley, P.E., Mellado-Ortega, E., Roberts, A.G., Stephens, J., Bryan, G.J., Torrance, L., Chapman, S.N., Prat, S. and Taylor, M.A. (2020). TERMINAL FLOWER-1/CENTRORADIALIS inhibits tuberisation via protein interaction with the tuberigen activation complex. Plant Journal. 103(6): 2263-2278. 